Agata Marcysiak

Adam Marcysiak

Uniwersytet Przyrodniczo-Humanistyczny w Siedlcach

\title{
Zarządzanie majątkiem jednostek gospodarczych o różnym profilu produkcji
}

\author{
MANAGEMENT OF ECONOMIC ASSETS WITH \\ VARIOUS PRODUCTION PROFILES
}

\begin{abstract}
Celem niniejszego opracowania jest próba ukazania zakresu zarzadzania majątkiem podmiotów gospodarczych o różnym profilu produkcji. Materiatem badawczym byly dane o gospodarstwach charakteryzujacych się zróżnicowanym profilem produkcji, które $w 2017$ roku prowadzity rachunkowość rolnq $w$ ramach polskiego FADN. Poszczególne wielkości ukazano w przeliczeniu $n a$ jedno gospodarstwo $w$ zł. Skale zróżnicowania analizowano $w$ podziale na osiem typów rolniczych. Majatek gospodarstwa przedstawiono w podziale na aktywa trwate i obrotowe. Rozpatrywanym parametrem oceny sprawności zarzqdzania majątkiem była efektywność wykorzystania zasobów. Najwyższym poziomem produktywności i dochodowości kapitalu odznaczały się gospodarstwa drobiarskie i ogrodnicze. Wysokim poziomem produktywności i dochodowości pracy odznaczaty się gospodarstwa nastawione na chów krów mlecznych i trzody chlewnej. O jakości zarzadzania podmiotu gospodarczego informuje także jego kondycja finansowa. Jej syntetycznym wskaźnikiem jest rentowność kapitału własnego ROE. W'śód analizowanych gospodarstw najwyższa dodatnia rentownościa kapitalu własnego odznaczaty się gospodarstwa drobiarskie. Wielkość wskaźnika ROE wynosiła tutaj 14,74\%. Na nieco niższym poziomie ksztaltowat się on w gospodarstwach, gdzie dominujaca produkcja byt chów krów mlecznych i trzody chlewnej. Dodatniq rentownościq odznaczaty się jeszcze gospodarstwa ogrodnicze.
\end{abstract}

Słowa kluczowe: ocena zarządzania majątkiem, kierowanie jednostką gospodarcza, aktywa trwałe i obrotowe, profil produkcji.

\section{Wprowadzenie}

Właściwe kierowanie działalnością gospodarczą implikuje ze sobą szereg wyzwań. Obszarem szczególnej odpowiedzialności staje się optymalne zarządzaniem majątkiem¹. Kierownicy gospodarstw, dążąc do poprawy swojej sytuacji finansowej, inwestują w środki trwałe, zwracając większą uwagę na ich ilość i ewentualnie jakość, mniejszą wage przywiązując do ich efektywnego wykorzystania ${ }^{2}$. Cechą charakterystyczną znacznej części gospodarstw rolnych w Polsce jest wysoka wartość środków trwałych w stosunku do posiadanego obszaru użytków rolnych oraz wysoki udział środków trwałych w wartości aktywów ogółem.

\footnotetext{
${ }^{1}$ J. Szabłowski (red): Strategie zarządzania majątkiem trwałym w organizacjach gospodarczych. Wyd. WSFiZ Białystok 2011, s. 45-56.

${ }^{2}$ D. Krzemińska (red.): Gospodarowanie majątkiem obrotowym w przedsiębiorstwie. Wyd. Akademii Ekonomicznej w Poznaniu. Poznań 2008, s. 35-47.
} 
Specyfiką produkcji rolniczej jest ścisły związek z przyrodniczymi warunkami produkcji. Zmusza to właścicieli gospodarstw do ponoszenia znacznych nakładów finansowych skierowanych na zakup środków trwałych zapewniających właściwą osłonę procesów produkcyjnych. Konsekwencją tego jest konieczność inwestowania w budynki i budowle zarówno te o charakterze produkcyjnym jak i pomocniczym. Często więc gospodarstwa, zwłaszcza te o mniejszym potencjale produkcyjnym, sa przeinwestowane, a okres zwrotu środków finansowych zainwestowanych w środki trwałe jest bardzo długi ${ }^{3}$.

Zróżnicowanie profilu produkcyjnego oraz różnorodność prowadzonej produkcji, często powiązanej ze zmiennością pór roku, obliguje do posiadania specjalistycznego sprzętu. Zmusza to rolników do wyposażania gospodarstw w sprzęt techniczny, niejednokrotnie wykorzystywany zaledwie przez kilkanaście, a nawet kilka dni w roku. Wpływa to na okres zwrotu zainwestowanych środków finansowych i przyczynia się do osiagania niskiej rentowności zaangażowanego kapitału.

Typ rolniczy stanowi jedno z kryteriów używanych dla charakteryzowania gospodarstwa rolnego we Wspólnotowej Typologii Gospodarstw Rolnych. Jest on określany na podstawie udziału wartości Standardowych Produkcji (SO) z poszczególnych działalności rolniczych $\mathrm{w}$ tworzeniu całkowitej wartości SO gospodarstwa ${ }^{4}$. Typ rolniczy gospodarstwa odzwierciedla jego poziom i kierunek specjalizacji ${ }^{5}$. W zależności od pożądanego stopnia dokładności, typy rolnicze gospodarstw są dzielone na: 8 typów ogólnych, 17 typów podstawowych, 50 typów szczegółowych.

\section{Metodyczne aspekty opracowania}

Celem niniejszego opracowania jest próba ukazania zakresu zarzadzania majątkiem podmiotów gospodarczych o różnym profilu produkcji.

Materiałem badawczym były dane o gospodarstwach charakteryzujących się zróżnicowanym typem rolniczym, które prowadziły rachunkowość rolną dla potrzeb Instytutu Ekonomiki Rolnictwa i Gospodarki Żywnościowej. Szczegółową analizą objęto rok 2017.

Podstawowymi kategoriami ekonomicznymi, przyjętymi dla potrzeb procesu badawczego były: wartość produkcji ogółem oraz poziom dochodu z gospodarstwa rolniczego Obliczeń tych kategorii dokonano metodą stosowaną w europejskim systemie rachunkowości rolnej FADN (Farm Accountancy Date Network).

Majątek gospodarstwa przedstawiono jako sumę aktywów trwałych i obrotowych. W obrębie aktywów trwałych analizie poddano cztery składniki a w przypadku aktywów obrotowych trzy składniki.

Dla oceny efektywności działan zarządczych w poszczególnych typach gospodarstw analizie poddano produktywność i dochodowość podstawowych czynników produkcji. Produktywność obliczono jako wartość produkcji rolniczej przypadającą na 1 ha UR, na 1 jednostkę przeliczeniową pracy AWU i na 1000 zł wartości rzeczowych środ-

\footnotetext{
${ }^{3}$ Grzywacz J. (red): Zarządzanie majątkiem obrotowym w przedsiębiorstwie. SGH Warszawa 2006. s. 75-89.

${ }^{4}$ Wyniki Standardowe 2017 uzyskane przez gospodarstwa rolne uczestniczące w Polskim FADN. IERiGŻ, Warszawa 2018, s. 10-12.

${ }^{5}$ M. Bocian, I. Cholewa: Standardowa produkcja w kontekście Wspólnotowej Typologii Gospodarstw Rolnych. Zagadnieniach Ekonomiki Rolnej nr 3, Warszawa 2013.

${ }^{6}$ Z Floriańczyk, B. Malanowska, D. Osuch, M. Bocian: Opis realizacji planu wyboru próby gospodarstw rolnych dla Polskiego FADN w 2017 roku. IERiGŻ, Warszawa 2017, s. 7-14.
} 
ków trwałych i obrotowych. Dochodowość ukazano jako wartość dochodu z gospodarstwa rolniczego przypadającą na 1 ha UR, na 1 jednostkę przeliczeniową pracy AWU i na 1000 zł wartości rzeczowych środków trwałych i obrotowych. Poszczególne wielkości przedstawiono $\mathrm{w}$ przeliczeniu na jedno gospodarstwo w zł. Skalę zróżnicowania analizowano w podziale na osiem typów rolniczych.

Działania w zakresie efektywności zarządzania majątkiem oceniono także na podstawie prowadzonej $\mathrm{w}$ analizowanych podmiotach gospodarki inwestycyjnej oraz sytuacji finansowej. Parametrami zastosowanymi do porównań w poszczególnych typach gospodarstw była wartość inwestycji brutto i netto w zł na jedno gospodarstwo, stopa reprodukcji majątku trwałego, wskaźnik rentowności kapitału własnego oraz wskaźnik bieżącej i podwyższonej płynności finansowej.

\section{Charakterystyka badanych gospodarstw}

Średni obszar badanego gospodarstwa w 2017 roku wynosił 19,7 ha UR. Analizowane gospodarstwa reprezentowały różne typy rolnicze. W próbie badawczej polskiego FADN liczacej 12293 gospodarstwa, pozycję dominująca zajmowały te, dla których główną działalnością biorącą udział w tworzeniu ogólnej wartości produkcji standardowej były uprawy polowe. Ich udział wynosił 33,0\%. Na drugim miejscu pod względem liczebności znalazły się gospodarstwa mieszane. Ten typ rolniczy stanowił $27,3 \%$ ogółu gospodarstw. Udział pozostałych typów rolniczych wynosił odpowiednio: krowy mleczne $21,6 \%$, zwierzęta trawożerne $-6,0 \%$, trzoda chlewna $-5,4 \%$, uprawy trwałe $-3,6 \%$, uprawy ogrodnicze $3,6 \%$ oraz drób - $0,6 \%$.

Poszczególne grupy gospodarstw wydzielone ze względu na typ rolniczy charakteryzowały się dużym zróżnicowaniem wyników produkcyjnych i ekonomicznych (tabela 1).

Tabela 1. Charakterystyka gospodarstw według typu rolniczego w 2017 roku

\begin{tabular}{|c|c|c|c|c|c|c|c|c|}
\hline Wyszczególnienie & $\begin{array}{l}\text { Upra- } \\
\text { wy } \\
\text { polowe }\end{array}$ & $\begin{array}{l}\text { Uprawy } \\
\text { ogrod- } \\
\text { nicze }\end{array}$ & $\begin{array}{l}\text { Uprawy } \\
\text { trwałe }\end{array}$ & $\begin{array}{l}\text { Kro- } \\
\text { wy } \\
\text { mle- } \\
\text { czne }\end{array}$ & $\begin{array}{c}\text { Zwierz. } \\
\text { trawo- } \\
\text { żerne }\end{array}$ & $\begin{array}{l}\text { Trzo- } \\
\text { da } \\
\text { chle- } \\
\text { wna }\end{array}$ & Drób & $\begin{array}{c}\text { Miesza- } \\
\text { ne }\end{array}$ \\
\hline Liczba gospodarstw & 4049 & 304 & 445 & 2659 & 739 & 668 & 77 & 3352 \\
\hline Powierzchnia UR w ha & 26,0 & 5,5 & 9,7 & 21,8 & 17,6 & 20,4 & 29,9 & 17,9 \\
\hline $\begin{array}{l}\text { Nakłady pracy ogółem w AWU } \\
\text { na } 1 \text { gospodarstwo }\end{array}$ & 155 & 236 & 184 & 1.81 & 1.41 & 165 & 4.09 & 158 \\
\hline Plony pszenicy $\mathrm{w} \mathrm{dt} / \mathrm{ha}$ & 60,8 & 42,5 & 46,4 & 52,4 & 49,7 & 59,5 & 58,3 & 57,3 \\
\hline Wyd. mlecz. krów w litrach & 4359 & 2396 & 2531 & 5696 & 4641 & 2729 & 3487 & 5393 \\
\hline Produkcja zwierz. na 1 LU & 3708 & 2782 & 6260 & 5719 & 2719 & 3603 & 6702 & 4159 \\
\hline Koszty bezpośrednie na 1 ha & 1601 & 11377 & 1989 & 2748 & 1330 & 7565 & 34743 & 2606 \\
\hline Koszty ogółem na 1 ha & 4042 & 28734 & 8088 & 5514 & 3227 & 10768 & 43433 & 5307 \\
\hline Koszt czynn. zewnęt. na 1 ha & 543 & 4464 & 1332 & 221 & 145 & 383 & 2591 & 490 \\
\hline $\begin{array}{l}\text { Wielkośc ekonomiczna } \\
\text { gospodarstwa w euro }\end{array}$ & 20303 & 44487 & 16312 & 31680 & 14980 & 54164 & 233822 & 19361 \\
\hline
\end{tabular}

Źródło: obliczenia własne na podstawie Wyniki Standardowe 2017 uzyskane przez gospodarstwa rolne uczestniczące w Polskim FADN. IERiGŻ, Warszawa 2018, s. 46-51.

Profil produkcji określony przez typ rolniczy gospodarstwa okazał się czynnikiem różnicującym zarówno obszar jak i wyniki produkcyjne gospodarstw. Największą powierzchnią użytków rolnych odznaczały się gospodarstwa nastawione na chów drobiu (29,9 ha) i uprawy polowe (26,1 ha). Istotną rolę obszar odgrywał także w gospodarstwach, w których dominującą działalnością biorącą udział w tworzeniu Standardowej 
Produkcji był chów krów mlecznych (21,8 ha) i trzody chlewnej (20,4 ha). Stosunkowo najmniejszymi były gospodarstwa specjalizujące się w uprawach ogrodniczych. Średni obszar wynosił tutaj zaledwie 5,5 ha UR.

Zgodnie z oczekiwaniami najlepsze wyniki dotyczące produkcji roślinnej osiaggano w gospodarstwach nastawionych na uprawy polowe. Średni plon pszenicy wynosił tutaj $60,8 \mathrm{dt} /$ ha. Najwyższą wydajnością mleczną (5696 litrów) odznaczały się gospodarstwa, w których dominował chów krów mlecznych. Z kolei gospodarstwami o najwyższych nakładach pracy ogółem były gospodarstwa drobiarskie $(4,09$ jednostki przeliczeniowej pracy AWU na 1gospodarstwo). One także charakteryzowały się najwyższą wartością produkcji zwierzęcej na $1 \mathrm{LU}$ oraz poziomem kosztów bezpośrednich i kosztów ogółem. Wynosiły one tutaj odpowiednio 6702 zł, 34743 zł oraz 43433 zł na 1 ha.

Ważnym parametrem oceny siły ekonomicznej gospodarstw w UE jest wielkość ekonomiczna. Określana jest ona jako suma wartości Standardowych Produkcji (SO) wszystkich działalności rolniczych występujących w gospodarstwie. Wielkość ekonomiczna gospodarstwa wyrażana jest wartością SO w euro. Do pola obserwacji Polskiego FADN przyjmuje się gospodarstwa rolne o minimalnej wielkości ekonomicznej 4000 euro $^{7}$. Wśród analizowanych gospodarstw największą wielkością ekonomiczną odznaczały się gospodarstwa specjalizujące się w chowie drobiu (233822 euro) i chowie trzody chlewnej (54164 euro) Dopiero na trzecim miejscu, w tak dokonanym zestawieniu, znalazły się gospodarstwa ogrodnicze (44487 euro). Niską wielkością ekonomiczną odznaczała się grupa gospodarstw nastawionych na uprawy trwałe wieloletnie oraz chów zwierząt trawożernych.

\section{Oddziaływanie profilu produkcji na zakres wsparcia gospodarstw środkami pochodzącymi z WPR UE}

Przeprowadzony podział na grupy wydzielone ze względu na typ rolniczy pozwolił ukazać zakres zróżnicowania sytuacji dochodowej w badanych gospodarstwach (rysunek 1).

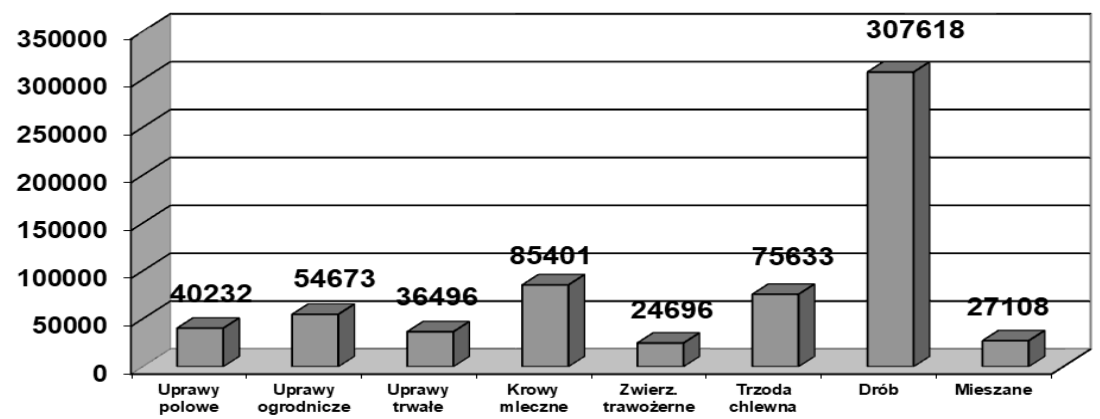

Rysunek. 1. Poziom dochodu z gospodarstwa rolniczego według typu rolniczego w 2017 roku [w zł] Źródło: obliczenia własne na podstawie Wyniki Standardowe 2017 uzyskane przez gospodarstwa rolne uczestniczące w Polskim FADN. IERiGŻ, Warszawa 2018, s. 51.

Poziom dochodu pochodzącego $\mathrm{z}$ działalności rolniczej $\mathrm{w}$ gospodarstwach prowadzących rachunkowość rolną dla potrzeb IERiGŻ w 2017 roku wynosił średnio 42181

\footnotetext{
${ }^{7}$ Z. Florianczyk, B Malanowska, D. Osuch, M. Bocian: Opis realizacji planu wyboru próby gospodarstw rolnych dla Polskiego FADN. IERiGŻ, Warszawa 2017, 9-15.
} 
$\mathrm{zl}^{8}$. W przeliczeniu na 1 ha UR była to kwota 2141 zł. Zdecydowanie najwyższym poziomem dochodu $\mathrm{z}$ gospodarstwa rolniczego wyróżniały się gospodarstwa zajmujące się chowem drobiu. Wynosił on tutaj ponad 307,6 tys. zł i był ponad 7,6 razy wyższy niż w gospodarstwach nastawionych na uprawy polowe. Na podobnym poziomie kształtował się on w gospodarstwach specjalizujących się w chowie krów mlecznych i trzody chlewnej. Tutaj średni poziom tej kategorii dochodu w przeliczeniu na 1 gospodarstwo wynosił odpowiednio ponad 85,4 tys. zł i 75,6 tys. zł. Najsłabiej pod względem ekonomicznym, w tym zestawieniu, wypadały gospodarstwa, gdzie dominował chów zwierząt trawożernych oraz te, określane jako mieszane, bez wyraźnej dominacji jednej działalności produkcyjnej. Ich dochód na 1 gospodarstwo wynosił w 2017 roku odpowiednio 24,6 tys. zł i 27,1 tys. zł.

Na sytuację ekonomiczną gospodarstw wpływ miały także instrumenty Wspólnej Polityki Rolnej UE. Wielkość płatności bezpośrednich do gruntów rolnych w gospodarstwach prowadzących rachunkowość rolną dla potrzeb IERiGŻ w 2017 roku wynosiła średnio 8812 zł. Udział tych płatności w ogólnej kwocie środków Wspólnej Polityki Rolnej UE przekazywanych do tych gospodarstw stanowił $69,0 \%$.

Zakres zróżnicowania poziomu płatności bezpośrednich do gruntów rolnych analizowanych gospodarstw w zależności od typu rolniczego gospodarstwa przedstawia tabela 2.

Tabela 2. Wielkość wsparcia środkami WPR UE według typu rolniczego gospodarstwa w roku 2017

\begin{tabular}{|c|c|c|c|c|c|c|c|c|}
\hline Wyszczególnienie & $\begin{array}{c}\text { Upra- } \\
\text { wy } \\
\text { polowe }\end{array}$ & $\begin{array}{c}\text { Uprawy } \\
\text { ogrod- } \\
\text { nicze }\end{array}$ & $\begin{array}{l}\text { Uprawy } \\
\text { trwałe }\end{array}$ & $\begin{array}{l}\text { Kro- } \\
\text { wy } \\
\text { mle- } \\
\text { czne }\end{array}$ & $\begin{array}{c}\text { Zwierz. } \\
\text { trawo- } \\
\text { żerne }\end{array}$ & $\begin{array}{c}\text { Trzo- } \\
\text { da } \\
\text { chle- } \\
\text { wna }\end{array}$ & Drób & $\begin{array}{l}\text { Miesza- } \\
\text { ne }\end{array}$ \\
\hline & \multicolumn{8}{|c|}{ W zł na 1 gospodarstwo } \\
\hline $\begin{array}{l}\text { Płatności bezpośrednie do } \\
\text { gruntów rolnych }\end{array}$ & 11749 & 2271 & 4331 & 10002 & 8099 & 9308 & 13779 & 7889 \\
\hline Płatności z tytułu ONW & 1352 & 381 & 802 & 2970 & 2912 & 1809 & 2843 & 1664 \\
\hline $\begin{array}{l}\text { Płatności rolno- } \\
\text { środowiskowo-klimatyczne }\end{array}$ & 1561 & 225 & 1148 & 803 & 3031 & 539 & 532 & 1140 \\
\hline $\begin{array}{l}\text { Inne dopłaty do rozwoju } \\
\text { obszarów wiejskich }\end{array}$ & 1074 & 175 & 1072 & 1026 & 843 & 1116 & 404 & 896 \\
\hline $\begin{array}{l}\text { Łącznie środki wypłacane w } \\
\text { ramach WPR UE }\end{array}$ & 15736 & 3052 & 7353 & 14801 & 14885 & 12772 & 17558 & 11589 \\
\hline
\end{tabular}

Źródło: obliczenia własne na podstawie Wyniki Standardowe 2017 uzyskane przez gospodarstwa rolne uczestniczące w Polskim FADN. IERiGŻ, Warszawa 2018, s. 46-51.

Analiza wykazała, że zakres zróżnicowania obszarowego w sposób jednoznaczny determinował wielkość środków pochodzących z płatności bezpośrednich w gospodarstwach. Największa wartość tych środków przypadła gospodarstwom drobiarskim i nastawionym na uprawy polowe (odpowiednio 13,7 tys. zł i 11,7 tys. zł). Stosunkowo najmniejsza kwota tego rodzaju płatności (2,2 tys. zł) powędrowała do gospodarstw ogrodniczych, obszarowo najmniejszych.

Istotnym elementem oddziaływania ze strony Wspólnej Polityki Rolnej UE jest wsparcie działalności rolniczej na obszarach o niekorzystnych warunkach gospodarowania. Ma ono na celu udzielenie pomocy finansowej gospodarstwom rolnym położonym

${ }^{8}$ Ł. Abramczuk, I. Augustyńska, A.Bębenista, M. Czułowska, A. Skarżyńska, M. Żekało: Wskaźniki zmian kosztów bezpośrednich i cen podstawowych produktów rolnych w latach 2017-2018. IERiGŻ, Warszawa 2018, s. 3-6. 
na terenach, na których produkcja rolnicza jest utrudniona ze względu na warunki naturalne. Płatności przyznawane dla gospodarstw z tytułu ONW mają przeciwdziałać wyludnianiu się obszarów wiejskich i zatracaniu ich rolniczego charakteru.

Wielkość płatności z tytułu ONW w gospodarstwach prowadzących rachunkowość rolną dla potrzeb IERiGŻ w 2017 roku wynosiła średnio 1754 zł. Tutaj liderem w pozyskiwaniu tych środków okazały się gospodarstwa nastawione na chów krów mlecznych oraz zwierząt trawożernych. Średnio na ten typ gospodarstw przypadło ponad 2,9 tys. zł.

Poza środkami z płatności bezpośrednich i płatności z tytułu ONW do analizowanych gospodarstw trafiały także dopłaty rolno-środowiskowo-klimatyczne oraz dopłaty do rozwoju obszarów wiejskich. Kwoty przypadające z tych źródeł średnio na gospodarstwo wynosiły w 2017 roku odpowiednio 1271 zł i 936 zł. Najwyższe kwoty płatności rolno-środowiskowo-klimatycznych otrzymały gospodarstwa specjalizujące się $\mathrm{w}$ chowie zwierząt trawożernych (średnia kwota wyniosła ponad 3,0 tys. zł). W przypadku dopłat do rozwoju obszarów wiejskich największe kwoty skierowano do gospodarstw zajmujących się chowem trzody chlewnej (średnio na gospodarstwo 1,1 tys. zł).

Środki przekazywane w ramach Wspólnej Polityki Rolnej nie pozostają obojętne na poziom dochodów pochodzących z produkcji rolniczej. W odniesieniu do analizowanych gospodarstw ogólna kwota wsparcia w ramach WPR UE w 2017 roku stanowiła 29,9\% dochodu z gospodarstwa rolniczego. Spośród różnych form pomocy najbardziej istotne oddziaływanie na sytuację dochodową rolników miały płatności bezpośrednie do gruntów rolnych oraz płatności z tytułu ONW (rysunek 2).

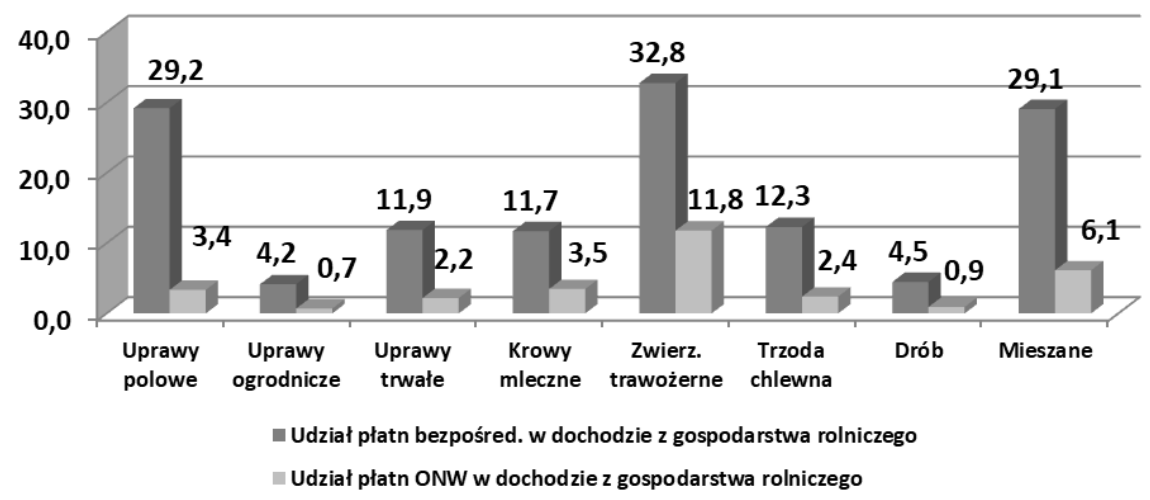

Rysunek. 2. Udział płatności bezpośrednich i płatności ONW w dochodzie z gospodarstwa rolniczego według typu rolniczego w 2017 roku [w \%]

Źródło: obliczenia własne na podstawie Wyniki Standardowe 2017 uzyskane przez gospodarstwa rolne uczestniczące w Polskim FADN. IERiGŻ, Warszawa 2018, s. 50-52.

Największe oddziaływanie płatności bezpośrednich na dochody miało miejsce w przypadku gospodarstw nastawionych na chów zwierząt trawożernych i gospodarstw o typie uprawy polowe. Ten typ płatności stanowił tutaj odpowiednio $32,8 \%$ i $29,2 \%$ dochodu z działalności rolniczej. Równie znaczące oddziaływanie wystąpiło w przypadku gospodarstw o typie mieszanym (39,3\%). Stosunkowo najmniejsze oddziaływanie na dochody, płatności bezpośrednie miały w gospodarstwach ogrodniczych. Tutaj ten typ płatności stanowił zaledwie $4,2 \%$ dochodu. 
W przypadku płatności z tytułu przynależności do obszarów o niekorzystnych warunkach gospodarowania największy ich udział w relacji do dochodu z gospodarstwa rolniczego występował w gospodarstwach specjalizujących się w chowie zwierząt trawożernych $11,8 \%$ ). Zdecydowanie najsłabsze oddziaływanie płatności z tytułu ONW na wyniki ekonomiczne, podobnie jak w przypadku płatności bezpośrednich miało miejsce w gospodarstw ogrodniczych.

\section{Rola i znaczenie środków trwałych i obrotowych $\mathrm{w}$ funkcjonowaniu analizowanych jednostek gospodarczych}

Znaczenie kapitału jako jednego z trzech podstawowych czynników produkcji w obszarze rolnictwa jest szczególnie istotna. Czynnik ten ma bowiem właściwości zarówno zastępowania (substytucji), jak i wspomagania pozostałych czynników wytwórczych ${ }^{9}$. W sposób bezpośredni oddziaływuje on na wielkość i wartość produkcji, a w konsekwencji także na poziom osiaganych wyników ekonomicznych. Zakres wyposażenia jednostek gospodarczych w środki trwałe implikuje także dobór sposobu zarządzania (tabela 3).

Tabela 3. Wielkość i struktura aktywów trwałych według typu rolniczego gospodarstwa w roku 2017

\begin{tabular}{|c|c|c|c|c|c|c|c|c|}
\hline Wyszczególnienie & $\begin{array}{c}\text { Upra- } \\
\text { wy } \\
\text { polowe }\end{array}$ & $\begin{array}{c}\text { Uprawy } \\
\text { ogrod- } \\
\text { nicze }\end{array}$ & $\begin{array}{c}\text { Uprawy } \\
\text { trwałe }\end{array}$ & $\begin{array}{c}\text { Kro- } \\
\text { wy } \\
\text { mle- } \\
\text { czne }\end{array}$ & $\begin{array}{c}\text { Zwierz. } \\
\text { trawo- } \\
\text { żerne }\end{array}$ & $\begin{array}{c}\text { Trzo- } \\
\text { da } \\
\text { chle- } \\
\text { wna }\end{array}$ & Drób & $\begin{array}{c}\text { Miesza- } \\
\text { ne }\end{array}$ \\
\hline & \multicolumn{8}{|c|}{ Wartość w zł na 1 gospodarstwo } \\
\hline Aktywa trwałe & 738831 & 465708 & 636862 & 866312 & 599375 & 899943 & 1475570 & 566343 \\
\hline Ziemia i uprawy trwałe & 489615 & 157137 & 397565 & 438282 & 365674 & 472895 & 477765 & 326594 \\
\hline Budynki i budowle & 126894 & 219666 & 139219 & 190535 & 128654 & 259678 & 734138 & 145406 \\
\hline Maszyny i urządzenia & 121241 & 88720 & 100064 & 168905 & 83579 & 154047 & 262051 & 82263 \\
\hline \multirow[t]{2}{*}{ Stado podstawowe } & 1081 & 186 & 13 & 68591 & 21468 & 13322 & 1617 & 12080 \\
\hline & \multicolumn{8}{|c|}{ Struktura $\mathrm{w} \%$} \\
\hline Aktywa trwałe & 100,0 & 100,0 & 100,0 & 100,0 & 100,0 & 100,0 & 100,0 & 100,0 \\
\hline Ziemia i uprawy trwałe & 66,3 & 33,7 & 62,4 & 50,6 & 61,0 & 52,5 & 32,4 & 57,7 \\
\hline Budynki i budowle & 17,2 & 47,2 & 21,9 & 22,0 & 21,5 & 28,9 & 49,7 & 25,7 \\
\hline Maszyny i urządzenia & 16,4 & 19,1 & 15,7 & 19,5 & 13,9 & 17,1 & 17,8 & 14,5 \\
\hline Stado podstawowe & 0,1 & 0,0 & 0,0 & 7,9 & 3,6 & 1,5 & 0,1 & 2,1 \\
\hline
\end{tabular}

Źródło: obliczenia własne na podstawie Wyniki Standardowe 2017 uzyskane przez gospodarstwa rolne uczestniczące w Polskim FADN. IERiGŻ, Warszawa 2018, s. 46-51.

Cechą charakterystyczną aktywów trwałych jest ich długi okres użytkowania. Będąc najważniejszym elementem majątku podmiotu gospodarczego, przenoszą swoją wartość na wyroby gotowe lub usługi, zachowując jednocześnie swoją postać naturalną przez cały okres eksploatacji. Właściwe zarządzanie środkami trwałymi i odpowiednie ich wykorzystanie gwarantują ciaggłość działalności gospodarczej i tym samym dalszy rozwój przedsiębiorstwa ${ }^{10}$. Cechą odróżniającą środki trwałe spośród reszty składników majątku, jest ich forma rzeczowa i przewidywany czas ekonomicznej użyteczności trwający dłużej niż jeden rok.

Wśród analizowanych gospodarstw zdecydowanie największą wartością środków trwałych wyróżniały się gospodarstwa drobiarskie. Tutaj wartość tych elementów

${ }^{9}$ G. K. Świderska (red.): Controling kosztów i rachunkowość zarządcza. Difin, Warszawa 2017. s. 260-269.

${ }^{10}$ P. Szczypa: Rachunkowość zarządcza. Klucz do sukcesu. Wyd. CeDeWu, Warszawa 2007. s. 125-131. 
majątku dwukrotnie przewyższała tą charakterystyczną dla gospodarstw z dominacją upraw polowych. Stosunkowo najsłabiej wyposażone $\mathrm{w}$ środki trwałe, na tle tego porównania, były gospodarstwa ogrodnicze. W przypadku wyposażenia w poszczególne składniki tworzące aktywa trwałe sytuacja była zróżnicowana. Z najwyższą wartością ziemi spotkać się można było $\mathrm{w}$ gospodarstwach nastawionych na uprawy polowe, a budynków i budowli oraz maszyn i urządzeń w gospodarstwach drobiarskich. Z kolei gospodarstwa zajmujące się chowem krów mlecznych wyróżniały się wysoką wartością stada podstawowego.

Pozycję dominująca, wynosząca powyżej 50\% w strukturze aktywów trwałych, ziemia i uprawy trwałe posiadały w każdym z typów gospodarstw za wyjątkiem ogrodniczych i drobiarskich. Tutaj wśród tych gospodarstw, w tym zestawieniu dominowały budynki i budowle.

Drugim elementem majątku podmiotu gospodarczego są aktywa obrotowe. Przeznaczone są one do zbycia lub zużycia $\mathrm{w}$ ciągu dwunastu miesięcy od dnia bilansowego lub w ciagu cyklu operacyjnego właściwego dla danej działalności. W klasyfikacji FADN do aktywów obrotowych zalicza się: stado obrotowe, zapasy oraz pozostałe aktywa obrotowe (tabela 4).

Tabela 4. Wielkość i struktura aktywów obrotowych według typu rolniczego gospodarstwa w roku 2017

\begin{tabular}{|c|c|c|c|c|c|c|c|c|}
\hline Wyszczególnienie & $\begin{array}{c}\text { Upra- } \\
\text { wy } \\
\text { polowe }\end{array}$ & $\begin{array}{c}\text { Uprawy } \\
\text { ogrod- } \\
\text { nicze }\end{array}$ & $\begin{array}{c}\text { Uprawy } \\
\text { trwałe }\end{array}$ & $\begin{array}{l}\text { Kro- } \\
\text { wy } \\
\text { mle- } \\
\text { czne }\end{array}$ & $\begin{array}{c}\text { Zwierz. } \\
\text { trawo- } \\
\text { żerne }\end{array}$ & $\begin{array}{l}\text { Trzo- } \\
\text { da } \\
\text { chle- } \\
\text { wna }\end{array}$ & Drób & $\begin{array}{c}\text { Miesza- } \\
\text { ne }\end{array}$ \\
\hline & \multicolumn{8}{|c|}{ Wartość w zł na 1 gospodarstwo } \\
\hline Aktywa obrotowe: & 96715 & 69634 & 61142 & 113651 & 83857 & 140710 & 454286 & 87437 \\
\hline Stado obrotowe & 2881 & 1191 & 135 & 29751 & 39183 & 55813 & 228090 & 24618 \\
\hline Zapasy produktów & 32550 & 26994 & 27926 & 35279 & 20814 & 38446 & 38746 & 26582 \\
\hline \multirow[t]{2}{*}{ Pozostałe aktywa obrotowe } & 61284 & 41449 & 33081 & 48621 & 23860 & 46451 & 187450 & 36237 \\
\hline & \multicolumn{8}{|c|}{ Struktura $\mathrm{w} \%$} \\
\hline Aktywa obroto & 100,0 & 100,0 & 100,0 & 100,0 & 100,0 & 100,0 & 100,0 & 100,0 \\
\hline Stado obrotowe & 3,0 & 1,7 & 0,2 & 26,2 & 46,7 & 39,7 & 50,2 & 28,2 \\
\hline Zapasy produktów & 33,6 & 38,8 & 45,7 & 31,0 & 24,8 & 27,3 & 8,5 & 30,4 \\
\hline Pozostałe aktywa obrotowe & 63,4 & 59,5 & 54,1 & 42,8 & 28,5 & 33,0 & 41,3 & 41,4 \\
\hline
\end{tabular}

Źródło: obliczenia własne na podstawie Wyniki Standardowe 2017 uzyskane przez gospodarstwa rolne uczestniczące w Polskim FADN. IERiGŻ, Warszawa 2018, s. 46-51.

W dokonanym zestawieniu, dotyczącym analizowanych gospodarstw, najwyższa wartość aktywów obrotowych widoczna była także w przypadku gospodarstw drobiarskich. Skala zróżnicowania pomiędzy tymi gospodarstwami a specjalizującymi się w uprawach polowych wyniosła ponad 4,6 razy i była zdecydowanie większa niż w porównaniu do aktywów trwałych.

$\mathrm{W}$ strukturze aktywów obrotowych $\mathrm{w}$ gospodarstwach specjalizujących się $\mathrm{w}$ chowie drobiarskim, chowie trzody chlewnej oraz zwierząt trawożernych pozycję dominująca posiadało stado obrotowe. W pozostałych typach gospodarstw, w tak dokonanym zestawieniu, dominowały pozostałe aktywa obrotowe.

Strukturę aktywów ogółem według typu rolniczego gospodarstw w 2017 roku przedstawia rysunek 3 . 


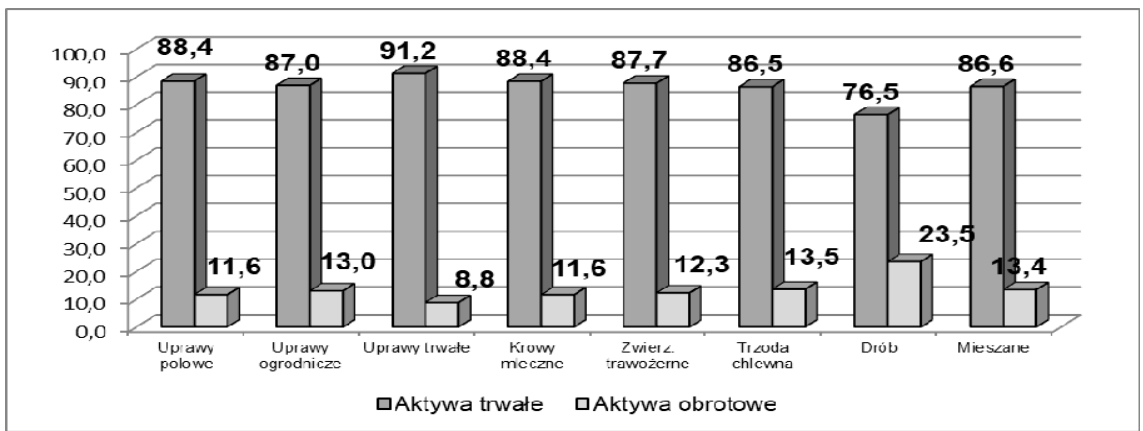

Rysunek 3. Struktura aktywów ogółem według typu rolniczego gospodarstw w 2017 roku [w \%] Źródło: obliczenia własne na podstawie Wyniki Standardowe 2017 uzyskane przez gospodarstwa rolne uczestniczące w Polskim FADN. IERiGŻ, Warszawa 2018, s. 51.

W strukturze wartościowej aktywów ogółem pozycję dominującą posiadały aktywa trwałe. Średnio w badanych gospodarstwach ich udział wynosił w 2017 roku 87,5\%. W analizowanych gospodarstwach najwyższy udział aktywów obrotowych wystapił w gospodarstwach drobiarskich $(23,5 \%)$ oraz tych nastawionych na chów trzody chlewnej $(13,5 \%)$. W przypadku gospodarstw prowadzących uprawy trwałe udział środków obrotowych stanowił już tylko 8,8\% aktywów ogółem.

\section{Efektywność zarządzania majątkiem w podmiotach o zróżnicowanym profilu produkcji}

Efektywność zarządzania majątkiem można oceniać na podstawie wielu kryteriów. Ziemia, praca i kapitał to podstawowe czynniki produkcji tworzące potencjał wytwórczy gospodarstwa rolnego. Wzajemne relacje występujące pomiędzy tymi czynnikami wpływają pośrednio i bezpośrednio na rozmiary możliwej do osiagnięcia produkcji i dochodu. Zakres wykorzystania poszczególnych zasobów można określić za pomocą produktywności i dochodowości ziemi, pracy i kapitału Pojęcia produktywności i dochodowości oznaczają wielkości produkcji i dochodu w przeliczeniu na jednostkę czynnika produkcji wyrażone w pieniądzu (tabela 5).

Tabela 5. Efektywność wykorzystania zasobów według typu rolniczego gospodarstwa w roku 2017

\begin{tabular}{|c|c|c|c|c|c|c|c|c|}
\hline Wyszczególnienie & $\begin{array}{c}\text { Upra- } \\
\text { wy } \\
\text { polowe }\end{array}$ & $\begin{array}{l}\text { Uprawy } \\
\text { ogrod- } \\
\text { nicze }\end{array}$ & $\begin{array}{c}\text { Uprawy } \\
\text { trwałe }\end{array}$ & $\begin{array}{c}\text { Kro- } \\
\text { wy } \\
\text { mle- } \\
\text { czne }\end{array}$ & $\begin{array}{c}\text { Zwierz. } \\
\text { trawo- } \\
\text { żerne }\end{array}$ & $\begin{array}{c}\text { Trzo- } \\
\text { da } \\
\text { chle- } \\
\text { wna }\end{array}$ & Drób & $\begin{array}{c}\text { Miesza- } \\
\text { ne }\end{array}$ \\
\hline & \multicolumn{8}{|c|}{ Produktywność w zł na 1 gospodarstwo } \\
\hline Produktywność ziemi & 4445 & 37462 & 10342 & 7832 & 3165 & 13199 & 52802 & 5555 \\
\hline Produktywność pracy & 74561 & 87306 & 54522 & 94333 & 39501 & 163187 & 386010 & 62935 \\
\hline \multirow[t]{2}{*}{ Produktywność kapitału } & 138 & 385 & 144 & 174 & 82 & 259 & 818 & 152 \\
\hline & \multicolumn{8}{|c|}{ Dochodowość w zł na 1 gospodarstwo } \\
\hline Dochodowość ziemi & 1547 & 9941 & 3762 & 3917 & 1403 & 3708 & 10288 & 1514 \\
\hline Dochodowość pracy & 25956 & 23167 & 19835 & 47183 & 17515 & 45838 & 75212 & 17157 \\
\hline Dochodowość kapitału & 48 & 102 & 52 & 87 & 36 & 73 & 159 & 41 \\
\hline
\end{tabular}

Źródło: obliczenia własne na podstawie Wyniki Standardowe 2017 uzyskane przez gospodarstwa rolne uczestniczace w Polskim FADN. IERiGŻ, Warszawa 2018, s. 46-51. 
Wyrażając produktywność ziemi użytkowanej rolniczo wartością produkcji rolniczej na 1 ha UR, można zauważyć, że wśród analizowanych gospodarstw najwyższą jej wartość odnotowano w gospodarstwach nastawionych na chów drobiu i uprawy ogrodnicze (odpowiednio 52802 zł i 37462 zł). Miało to bezpośredni związek ze skalą intensywności produkcji prowadzonej $\mathrm{w}$ tych gospodarstwach. Podobny układ zależności miał miejsce w przypadku produktywności kapitału. Obliczono go jako wartość produkcji rolniczej przypadającej na 1000 zł wartości rzeczowych środków trwałych i obrotowych. W tych dwóch typach gospodarstw wyniósł on odpowiednio 818 zł i 385zł. W odniesieniu do produktywności pracy - mierzonej wartością produkcji rolniczej przypadającej na jednostkę przeliczeniowa pracy (AWU), najwyższy jej poziom wystapił w gospodarstwach drobiarskich i tych nastawionych na chów trzody chlewnej. Zdecydowanie najniższym poziomem każdej z typów produktywności odznaczały się gospodarstwa zajmujące się chowem zwierząt trawożernych.

Osiągana wartość produkcji rolniczej przez poszczególne typy analizowanych gospodarstw wpływała na ich wyniki ekonomiczne. Dochodowość ziemi pracy i kapitału swą najwyższą wielkość osiagnęła w gospodarstwach drobiarskich. Podobnie jak w przypadku produktywności także dochodowość ziemi i kapitału najniższą wielkość osiągnęła $\mathrm{w}$ gospodarstwach specjalizujących się $\mathrm{w}$ chowie zwierząt trawożernych. W odniesieniu do dochodowości pracy najniższą jej wielkość odnotowano w gospodarstwach nie posiadających wyraźnego profilu produkcji. Wyniosła ona tutaj zaledwie 17157 zł na jednostkę przeliczeniową pracy AWU.

Ważnym parametrem oceny sprawności zarządzania jest wielkość wyniku finansowego netto. Jest on obliczany jako różnica między dochodem $\mathrm{z}$ rodzinnego gospodarstwa rolnego a kosztami pracy własnej rolnika i jego rodziny (tabela 6).

Tabela 6. Wynik finansowy netto i parytet dochodowy według typu rolniczego gospodarstwa w roku 2017

\begin{tabular}{|c|c|c|c|c|c|c|c|c|}
\hline Wyszczególnienie & $\begin{array}{c}\text { Upra- } \\
\text { wy } \\
\text { polowe }\end{array}$ & $\begin{array}{c}\text { Uprawy } \\
\text { ogrod- } \\
\text { nicze }\end{array}$ & $\begin{array}{c}\text { Uprawy } \\
\text { trwałe }\end{array}$ & $\begin{array}{l}\text { Kro- } \\
\text { wy } \\
\text { mle- } \\
\text { czne }\end{array}$ & $\begin{array}{c}\text { Zwierz. } \\
\text { trawo- } \\
\text { żerne }\end{array}$ & $\begin{array}{c}\text { Trzo- } \\
\text { da } \\
\text { chle- } \\
\text { wna } \\
\end{array}$ & Drób & $\begin{array}{c}\text { Miesza- } \\
\text { ne }\end{array}$ \\
\hline & \multicolumn{8}{|c|}{ w zł na 1 gospodarstwo } \\
\hline Koszt pracy włas & 47082 & 54382 & 48907 & 64601 & 50367 & 56572 & 58032 & 53287 \\
\hline Wynik finansowy netto $\mathrm{w} z l$ & -6850 & 291 & -12411 & 20800 & -25671 & 19061 & 249586 & -26179 \\
\hline $\begin{array}{lcc}\text { Dochód } & \mathrm{z} & \text { działalności } \\
\text { rolniczej na } 1 & \text { godz. pracy }\end{array}$ & & & & & & & & \\
\hline własnej & 14,18 & 16,68 & 12,38 & 21,93 & 8,13 & 22,18 & 87,94 & 8,44 \\
\hline Parytet dochodowy & 0,85 & 1,01 & 0,75 & 1,32 & 0,49 & 1,34 & 5,30 & 0,51 \\
\hline
\end{tabular}

Źródło: obliczenia własne na podstawie Wyniki Standardowe 2017 uzyskane przez gospodarstwa rolne uczestniczące w Polskim FADN. IERiGŻ, Warszawa 2018, s. 46-51.

Koszty pracy rolnika zostały obliczone jako iloczyn nakładów pracy własnej wyrażonej w godzinach i stawki parytetowej. Stawka ta w 2017 roku wynosiła 16,59 zł i odpowiadała średniorocznemu wynagrodzeniu netto w gospodarce narodowej określonemu przez GUS ${ }^{11}$. Średnio na jedno analizowane gospodarstwo koszty pracy własnej wyniosły 52922 zt.

\footnotetext{
${ }^{11}$ A. Skarżyńska, $\_$Abramczuk: Wyniki ekonomiczne wybranych produktów w 2017 roku-IERiGŻ nr 2 (355), Warszawa 2018, s. 140-142.
} 
Nadwyżka dochodu, nad tak obliczonymi kosztami pracy własnej rolnika, wystapiła w gospodarstwach specjalizujących się w krów mlecznych, trzody chlewnej, drobiu oraz gospodarstwach ogrodniczych. Ten rodzaj gospodarstw w literaturze przedmiotu określany bywa jako gospodarstwa rozwojowe ${ }^{12}$. Ich właściwe zarządzanie aktywami trwałymi i obrotowymi sprawia, iż osiągają one wyższy poziom dochodu z pracy w gospodarstwie niż dochód parytetowy. Parytet dochodowy obliczono jako relację dochodu z rodzinnego gospodarstwa $\mathrm{w}$ przeliczeniu na 1 godzinę pracy własnej do stawki parytetowej określonej według GUS. W pozostałych typach gospodarstw wynik finansowy netto był ujemny.

Poziom dochodu z rodzinnego gospodarstwa rolnego decyduje o konkurencyjności tych podmiotów. Im wyższy jest jego poziom, tym większa skłonność rolników do rozwijania gospodarstwa poprzez inwestowanie w środki trwałe. Prowadzenie działalności inwestycyjnej w gospodarstwach rolnych jest jednym z ważniejszych mierników przy ocenie perspektyw rozwoju. Sprawne i efektywne funkcjonowanie gospodarstw rolnych nie jest możliwe bez wprowadzania innowacyjnych rozwiązań i inwestowanie w trwałe środki produkcji. Prowadzi to do poprawy efektywności ogółu posiadanych czynników wytwórczych.

Działalność inwestycyjna świadczy o sytuacji ekonomicznej i jest wyrazem właściwie prowadzonego procesu zarządzania majątkiem w gospodarstwie rolnym. $\mathrm{O}$ rzeczywistym przyroście inwestycji informuje wartość inwestycji netto. W przypadku, gdy wartość ta jest ujemna oznacza to, że następuje w nich dekapitalizacja majątku trwałego. Świadczy o tym również ujemna stopa reprodukcji majątku trwałego. Można przypuszczać wówczas, że wartość podejmowanych inwestycji jest zbyt mała i nie rekompensuje utraty wartości majątku na wskutek jego amortyzacji (tabela 7).

Tabela 7. Charakterystyka działalności inwestycyjnej i sytuacji finansowej gospodarstw według typu rolniczego gospodarstwa w 2017 roku

\begin{tabular}{|l|r|r|r|r|r|r|r|r|}
\hline \multicolumn{1}{|c|}{ Wyszczególnienie } & $\begin{array}{c}\text { Upra- } \\
\text { wy } \\
\text { polowe }\end{array}$ & $\begin{array}{c}\text { Uprawy } \\
\text { ogrod- } \\
\text { nicze }\end{array}$ & $\begin{array}{c}\text { Uprawy } \\
\text { trwałe }\end{array}$ & $\begin{array}{c}\text { Kro- } \\
\text { wy } \\
\text { mle- } \\
\text { czne }\end{array}$ & $\begin{array}{c}\text { Zwierz. } \\
\text { trawo- } \\
\text { żerne }\end{array}$ & $\begin{array}{c}\text { Trzo- } \\
\text { da } \\
\text { chle- } \\
\text { wna }\end{array}$ & $\begin{array}{c}\text { Drób } \\
\text { Miesza- } \\
\text { ne }\end{array}$ \\
\hline $\begin{array}{l}\text { Inwestycje brutto (w zł na } \\
\text { gosp.) }\end{array}$ & 14643 & 12505 & 21575 & 28074 & 9285 & 26544 & 20846 & 11128 \\
$\begin{array}{l}\text { Amortyzacja (w zł na gosp.) } \\
\text { Inwestycje netto (w zł na }\end{array}$ & 22022 & 25485 & 30035 & 26223 & 16045 & 27602 & 70331 & 17140 \\
$\begin{array}{l}\text { gosp.) } \\
\text { Stopa reprodukcji majątku } \\
\text { trwałego w \% }\end{array}$ & -7379 & -12980 & -8460 & 1851 & -6760 & -1058 & -49485 & -6012 \\
$\begin{array}{l}\text { Wskaźnik rent. kapitału } \\
\text { własnego ROE w \% }\end{array}$ & $-1,00$ & $-2,79$ & $-1,33$ & 0,21 & $-1,13$ & $-0,12$ & $-3,35$ & $-1,06$ \\
$\begin{array}{l}\text { Wskaźnik bieżącej płynno- } \\
\text { ści finansowej }\end{array}$ & 6,82 & 0,06 & $-1,85$ & 2,23 & $-3,86$ & 1,96 & 14,64 & $-4,15$ \\
$\begin{array}{l}\text { Wskaźnik płynności przy- } \\
\text { spieszonej }\end{array}$ & 4,27 & 6,88 & 10,10 & 16,18 & 8,06 & 7,51 & 9,86 \\
\hline
\end{tabular}

Źródło: obliczenia własne na podstawie Wyniki Standardowe 2017 uzyskane przez gospodarstwa rolne uczestniczące w Polskim FADN. IERiGŻ, Warszawa 2018, s. 48-52.

${ }^{12}$ Z Gołaś: Uwarunkowania rentowności kapitału własnego w rolnictwie. Zagadnienia Ekonomiki Rolnej nr 4, Warszawa 2008, s. 76-89. 
W odniesieniu do analizowanych gospodarstw, tylko w przypadku tych nastawionych na chów krów mlecznych, wartość inwestycji netto była dodatnia i wynosiła 1851 zł. Stopa reprodukcji majątku trwałego, obliczana jako relacja wartości inwestycji netto do wartości środków trwałych, w tym przypadku wyniosła 0,21\%. Występująca reprodukcja rozszerzona świadczy o tym, że dokonuje się tutaj nie tylko proste odtworzenie zużytych środków produkcji, ale ma miejsce także, choć powolne ale jednak, zwiększanie i unowocześnianie aparatu wytwórczego.

Jakość zarządzania można ocenić także na podstawie kondycji finansowej gospodarstw rolnych. Wskaźnik rentowności kapitału własnego ROE oblicza się jako relację wyniku finansowego netto i kapitału własnego. Przedstawia on zdolność gospodarstwa do wypracowania zysku netto z jednej złotówki kapitału własnego ${ }^{13}$. Jest on najbardziej syntetycznym wskaźnikiem rentowności, gdyż uwzględnia wszelkie skutki decyzji i działań operacyjnych, inwestycyjnych i finansowych ${ }^{14}$. Zdecydowanie najwyższą dodatnią rentownością kapitału własnego odznaczały się gospodarstwa drobiarskie. Wielkość wskaźnika ROE wynosiła tutaj 14,74\%. Na znacznie niższym poziomie kształtował się on w gospodarstwach, gdzie dominującym kierunkiem produkcji były krowy mleczne i trzoda chlewna (odpowiednio 2,23\% i 1,96\%). Dodatnią rentownością odznaczały się jeszcze gospodarstwa ogrodnicze.

O umiejętności właściwego kierowania podmiotem gospodarczym informuje również wskaźnik płynności finansowej ${ }^{15}$. Z danych przedstawionych w tabeli 7 wynika, że we wszystkich porównywanych typach gospodarstw wskaźnik bieżącej płynności finansowej znacząco odbiegał od wartości optymalnych (powinny one wynosić 1,5$\left.2,0^{16}\right)$. Specyfika rolnictwa sprawia, iż występuje tutaj wolny obrót kapitału. Środki zainwestowane w aktywa obrotowe są zwracane dopiero po zakończonym cyklu produkcyjnego, który zazwyczaj trwa jeden rok. Nie ma wówczas możliwości wcześniejszego zbycia części tego majątku, nawet jeśli rachunek ekonomiczny na to wskazuje. Wśród analizowanych gospodarstw szczególnie wysokie wartości wskaźnika bieżącej płynności finansowej odnotowano w przypadku gospodarstw, o niskim potencjale produkcyjnym, nastawionych na chów zwierząt trawożernych. Wielkość tego wskaźnika wyniosła tutaj aż 16,18. Właściciele tych gospodarstw zbyt mało inwestowali w rozwój, a zasób środków obrotowych, nie był wykorzystywany racjonalnie. Inna sytuacja miała miejsce w przypadku gospodarstw ogrodniczych. W gospodarstwach tych wskaźnik bieżącej płynności finansowej wynosił 4,27 a podwyższonej płynności finansowej 2,61. Osoby odpowiedzialne za zarządzanie tymi gospodarstwami właściwie ustalali proporcje pomiędzy zasobami środków trwałych i obrotowych. Sprzyjał im także charakter produkcji ogrodniczej pozwalający często na wykonanie kilku cykli produkcyjnych w ciągu roku.

\footnotetext{
${ }^{13}$ J. Dyktus, M. Gaertner, B. Malik: Sprawozdawczość i analiza finansowa. Dyfin, Warszawa 2017, s. 121.

${ }^{14}$ E. Nowak: Analiza sprawozdań finansowych. PWE, Warszawa 2017, s. 220-225.

${ }^{15}$ M. Sierpińska, D. Wędzki: Zarządzanie płynnością finansową w przedsiębiorstwie, Wydawnictwo Naukowe PWN, Warszawa 2010, s. 220-224.

${ }^{16}$ W. Gabrusewicz: Podstawy analizy finansowej. PWE Warszawa 2002, s. 250-254.
} 


\section{Wnioski}

Reasumując dotychczasowe rozważania można sformułować następujące wnioski:

- Profil produkcji okazał się czynnikiem różnicującym wielkość i strukturę majątku analizowanych podmiotów gospodarczych. Zdecydowanie największą wartością środków trwałych wyróżniały się gospodarstwa drobiarskie. Tutaj wartość tych elementów majątku dwukrotnie przewyższała tą charakterystyczną dla gospodarstw z dominacją upraw polowych. W strukturze wartościowej aktywów trwałych, pozycję dominująca, wynosząca powyżej $50 \%$, ziemia i uprawy trwałe posiadały w każdym z typów gospodarstw za wyjątkiem ogrodniczych i drobiarskich. Tutaj wśród tych gospodarstw, w tym zestawieni dominowały budynki i budowle. Aktywa trwałe dominowały także w strukturze aktywów ogółem. Średnio w badanych gospodarstwach ich udział wynosił w 2017 roku 87,5\%. W analizowanych gospodarstwach najwyższy udział aktywów obrotowych wystąpił w gospodarstwach drobiarskich $(23,5 \%)$ oraz w tych nastawionych na chów trzody chlewnej $(13,5 \%)$.

- Parametrem oceny sprawności zarządzania majątkiem może być efektywność wykorzystania zasobów. Najwyższym poziomem produktywności i dochodowości kapitału odznaczały się gospodarstwa drobiarskie i ogrodnicze. Wysokim poziomem produktywności i dochodowości pracy odznaczały się również gospodarstwa nastawione na chów krów mlecznych i trzody chlewnej.

- Właściwie prowadzona działalność inwestycyjna świadczy o jakości procesu zarządzania majątkiem. Wartość inwestycji netto informuje wówczas o rzeczywistym przyroście inwestycji w jednostce gospodarczej. W odniesieniu do analizowanych gospodarstw tylko $\mathrm{W}$ przypadku tych nastawionych na chów krów mlecznych wartość inwestycji netto była dodatnia. Stopa reprodukcji majątku trwałego obliczana jako relacja wartości inwestycji netto do wartości środków trwałych w tym przypadku wyniosła $0,21 \%$. Dokonująca się tutaj reprodukcja rozszerzona świadczy o realnym zwiększeniu i unowocześnieniu majątku.

- Ważnym parametrem oceny jakości zarządzania jest także kondycja finansowa podmiotu gospodarczego. O jej stanie informuje m. in. wskaźnik rentowności kapitału własnego ROE. Uwzględnia on bowiem wszelkie skutki decyzji i działań operacyjnych, inwestycyjnych i finansowych podmiotu. Obowiązuje tutaj zależność mówiąca o tym iż, im większa jest rentowność, tym lepsze są perspektywy rozwojowe gospodarstwa i więcej środków można przeznaczyć na zakup poszczególnych składników majątku. Wśród analizowanych gospodarstw najwyższą dodatnią rentownością kapitału własnego odznaczały się gospodarstwa drobiarskie. Wielkość wskaźnika ROE wynosiła tutaj 14,74\%. Na nieco niższym poziomie kształtował się on w gospodarstwach, gdzie dominująca produkcją był chów krów mlecznych i trzody chlewnej. Dodatnią rentownością odznaczały się jeszcze gospodarstwa ogrodnicze.

\section{Bibliografia}

Abramczuk Ł., Augustyńska I., Bębenista A., Czułowska M., Skarżyńska A., Żekało M.: Wskaźniki zmian kosztów bezpośrednich i cen podstawowych produktów rolnych w latach 2017-2018. IERiGŻ, Warszawa 2018.

Bocian M., Cholewa I.: Standardowa produkcja w kontekście Wspólnotowej Typologii Gospodarstw Rolnych. Zagadnieniach Ekonomiki Rolnej nr 3, Warszawa 2013

Dyktus J., Gaertner M., Malik B.: Sprawozdawczość i analiza finansowa. Dyfin, Warszawa 2017. Floriańczyk Z, Malanowska B., Osuch D., Bocian M.: Opis realizacji planu wyboru próby gospodarstw rolnych dla Polskiego FADN w 2017 roku. IERiGŻ, Warszawa 2017. 
Gabrusewicz W.: Podstawy analizy finansowej. PWE Warszawa 2002.

Gołaś Z.: Uwarunkowania rentowności kapitału własnego w rolnictwie. Zagadnienia Ekonomiki Rolnej nr 4, Warszawa 2008.

Grzywacz J. (red): Zarządzanie majątkiem obrotowym w przedsiębiorstwie. SGH Warszawa 2006. Krzemińska D. (red.): Gospodarowanie majątkiem obrotowym w przedsiębiorstwie. Wyd. Akademii Ekonomicznej w Poznaniu. Poznań 2008.

Nowak E.: Analiza sprawozdań finansowych. PWE, Warszawa 2017

Sierpińska M., Wędzki D.: Zarządzanie płynnością finansową w przedsiębiorstwie, Wydawnictwo Naukowe PWN, Warszawa 2010

Skarżyńska A.: Abramczuk Ł: Wyniki ekonomiczne wybranych produktów w 2017 roku -IERiGŻ nr 2 (355), Warszawa 2018

Szabłowski J. (red): Strategie zarządzania majątkiem trwałym w organizacjach gospodarczych. Wyd. WSFiZ Białystok 2011.

Szczypa P.: Rachunkowość zarządcza. Klucz do sukcesu. Wyd. CeDeWu Warszawa 2007.

Świderska G. K. (red.): Controling kosztów i rachunkowość zarządcza. Difin, Warszawa 2017.

Wyniki Standardowe 2017 uzyskane przez gospodarstwa rolne uczestniczące w Polskim FADN. IERiGŻ, Warszawa 2018.

\section{Summary}

The aim of this study is to show the scope of asset management of business entities with different production profiles. The research material was data on farms characterized by diversified production profile, which in 2017 conducted agricultural accounting under the Polish FADN. Individual sizes are shown per one household in PLN. The scale of diversification was analyzed by eight types of farming. The property of the holding is presented broken down into non-current and current assets. The efficiency of resource utilization was considered as the parameter of assessing the efficiency of asset management. Poultry and gardening farms were characterized by the highest level of productivity and profitability of capital. Farms with milk cows and pigs were characterized by a high level of productivity and profitability of work. The financial condition of the business entity also informs its financial condition. Its synthetic indicator is the profitability of ROE's equity. Among the analyzed farms, poultry farms showed the highest positive return on equity. The value of ROE was $14.74 \%$ here. At a slightly lower level, it was shaped on farms where the dominant production was dairy cows and pigs rearing. Gardening farms also had a positive profitability.

Key words: assessment of asset management, management of the economic unit, fixed and current assets, production profile.

Informacja o autorze:

Dr inż. Agata Marcysiak

Uniwersytet Przyrodniczo-Humanistyczny w Siedlcach

Wydział Nauk Ekonomicznych i Prawnych, Instytut Nauk o Zarządzaniu i Jakości

ul Żytnia 17/19, 08-110 Siedlce

agata.marcysiak@uph.edu.pl

ORCID: 0000-0003-2534-9877

Dr inż. Adam Marcysiak

Uniwersytet Przyrodniczo-Humanistyczny w Siedlcach

Wydział Nauk Ekonomicznych i Prawnych, Instytut Nauk o Zarządzaniu i Jakości

ul Żytnia 17/19; 08-110 Siedlce

adam.marcysiak@uph.edu.pl

ORCID: 0000-0002-3132-8565 